\title{
ANALYSIS OF MILK RECORDS OF BUFFALOES COLLECTED UNDER DIFFERENT PRODUCTION SYSTEMS
}

\author{
S.A.M. Abdel-Salam, S. Abou-Bakr, M.A.M. Ibrahim, R. R. Sadek and \\ A. S. Abdel-Aziz
}

Department of Animal Production, Faculty of Agriculture, Cairo University, Giza, Egypt

\section{SUMMARY}

A total of 3526 lactation records of 2179 buffaloes in 51 herds in 8 governorates under four production systems were recorded by the Cattle Information System/Egypt (CISE) of the Faculty of Agriculture, Cairo University during the period from 1990 to 2006 . The records were used to estimate non-genetic effects on total milk yield of recorded Egyptian buffaloes. The highest least squares means of total milk yield was $2044 \mathrm{~kg}$ milk in Fayoum governorate, while the lowest was 1444 $\mathrm{kg}$ milk in Ismalia governorate. The differences between least squares means of total milk yield in different production systems was highly significant $(\mathrm{p}<0.01)$. The least squares means of total milk yield of commercial, experimental, flying and small holder production systems were 1844, 1328, 1993 and $1770 \mathrm{~kg}$, respectively. The least squares means of total milk yield of buffaloes in the first six parities ranged from $1579 \mathrm{~kg}$ for the first parity to $1808 \mathrm{~kg}$ for the sixth parity.

Keywords: Total milk yield, Egyptian buffalo, fixed effects, production system

\section{INTRODUCTION}

The contribution of buffalo to total milk production in Egypt is around 50 per cent (FAOSTAT 2008). According to the FAOSTAT (2008) the Egyptian buffaloes contribute about 2.5 and $8 \%$ of the world buffalo's milk and meat, respectively. Information about the phenotypic and genetic parameters of various economic traits is essential for the selection of higher productivity and efficient production systems. The formulation of breeding plans and genetic improvement necessitate defining and analyzing the production systems of Egyptian buffaloes. The aim of this research was to study phenotypic parameters of total milk yield of buffalo under different production systems in Egypt.

There are different buffalo production systems in Egypt. The first is the traditional crop/livestock system (small holders) which is traditionally integrated with the dominating agricultural system. It contains about $96 \%$ of the cattle and buffalo population and produces about $70 \%$ of the total domestic milk output. The second system is the intensive production system which contains large commercial farms. Commercial farms contain about $4 \%$ of the total cattle and buffalo population but produce about $30 \%$ of the marketable milk. The third system raising buffalo is called flying system. In this system, buffaloes are put under very intensive feeding regimes 
to produce high-fat milk. The fourth production system is experimental farms which keep the buffalo for educational, training and research purposes.

\section{MATERIALS AND METHODS}

Data

This study was carried out using milk production records of buffalo herds recorded by the Cattle Information System/Egypt (CISE) of Cairo University, Faculty of Agriculture during the period from 1990 to 2006, which were used to estimate non-genetic parameters of total milk yield of recorded Egyptian buffaloes.

The data comprised 3526 lactation records of 2179 buffaloes in 51 herds at 8 governorates under four production systems were used. The animals under small holder system in the same village considered as one herd. The eight governorates were Elbehera, Baniswif, Fayoum, Giza, Ismalia, Kaliobia, Elminia and Sharkia. The four production systems were commercial, experimental, flying and small holder herds (Table 1). Parities included the first six lactations.

Table 1. Distribution of herds in different production system by governorates

\begin{tabular}{lccccc}
\hline \multirow{2}{*}{ Governorate } & \multicolumn{4}{c}{ Production System } & \\
\cline { 2 - 5 } & Commercial & Experimental & Flying & $\begin{array}{c}\text { Small } \\
\text { holder }\end{array}$ & Total \\
\hline Elbehera & 2 & 1 & - & 7 & 10 \\
Baniswif & 2 & - & - & 2 & 4 \\
Fayoum & 1 & - & - & 4 & 5 \\
Giza & 3 & 4 & 7 & 5 & 19 \\
Ismalia & 2 & - & - & - & 2 \\
Kaliobia & 2 & 1 & - & - & 3 \\
Elminia & 1 & - & - & 5 & 6 \\
Sharkia & 2 & - & - & - & 2 \\
\hline Total & 15 & 6 & 7 & 23 & 51 \\
\hline
\end{tabular}

This study was focused on estimating total milk yield of Egyptian buffaloes under different production systems.

Statistical Analysis

1- The following fixed model was used to estimate the least squares means of total milk yield of buffaloes in different governorates, production systems and parities; using the General Linear Model (GLM) procedure (SAS, 2001).

$\mathrm{Y}_{\mathrm{ijklm}}=\mu+\mathrm{G}_{\mathrm{i}}+\mathrm{S}_{\mathrm{j}}+\mathrm{P}_{\mathrm{k}}+\mathrm{YS}_{\mathrm{l}}+\mathrm{e}_{\mathrm{ijklm}}$

Where:

$\mathrm{Y}_{\mathrm{ijklm}}=$ observation of total milk yield;

$\mu=$ overall mean;

$\mathrm{G}_{\mathrm{i}}=$ fixed effect of governorate $\mathrm{i},(\mathrm{i}=8)$;

$\mathrm{S}_{\mathrm{j}}=$ fixed effect of production system $\mathrm{j},(\mathrm{j}=4)$;

$\mathrm{P}_{\mathrm{k}}=$ fixed effect of parity $\mathrm{k},(\mathrm{k}=6$ parities $)$;

$\mathrm{YS}_{1}=$ fixed effect of year-season of calving $1,(1=32)$ and

$\mathrm{e}_{\mathrm{ijklm}}=$ random residual effect. 


\section{RESULTS AND DISCUSSION}

The least squares means of total milk yield of recorded buffalo ranged from 2044 $\mathrm{kg}$ milk in Fayoum governorate to $1444 \mathrm{~kg}$ milk in Ismalia governorate (table 2). The difference in total milk yield between governorates is due mainly to the environment, management and prevailing production systems.

Table 2. Least squares means(X) of total milk yield (kg) and their standard error (SE) of buffaloes in eight governorates

\begin{tabular}{lccc}
\hline Governorate & No. of records & $\mathrm{X}(\mathrm{kg})^{*}$ & $\mathrm{SE}$ \\
\hline Fayoum & 334 & $2044^{\mathrm{b}}$ & 36 \\
Giza & 1496 & $1873^{\mathrm{c}}$ & 21 \\
Elminia & 318 & $1846^{\mathrm{ce}}$ & 36 \\
Kaliobia & 385 & $1767^{\mathrm{ef}}$ & 35 \\
Baniswif & 229 & $1652^{\mathrm{a}}$ & 41 \\
Sharkia & 46 & $1639^{\mathrm{af}}$ & 77 \\
Behera & 660 & $1603^{\mathrm{a}}$ & 27 \\
Ismalia & 58 & $1444^{\mathrm{d}}$ & 68 \\
\hline
\end{tabular}

* Means followed by different letters differ significantly $(\mathrm{p}<0.01)$.

Table 3 shows the least squares means of total milk yield in different types of buffalo production systems in Egypt. The highest production was $1993 \mathrm{~kg}$ milk yield for flying herds which raise very highly producing buffaloes. The flying herds use good management and high quality feed to produce more milk. This system is usually located in the outskirt of cities. Also, the lactation period was the longest (326 day) in this system. While the least squares means of total milk yield of buffalo under commercial herds was $1844 \mathrm{~kg}$ milk. These commercial herds have high producing animals, good management, and nutrition system and use machine milking.

Table 3. Least squares means $(\mathrm{X})$ of total milk yield $(\mathrm{kg})$ and their standard error (SE) and average lactation period (LP) in days of buffaloes under different production systems

\begin{tabular}{lcccc}
\hline Production systems & $\begin{array}{c}\text { No. of } \\
\text { records }\end{array}$ & $\mathrm{X}(\mathrm{kg})^{*}$ & SE & LP, day \\
\hline Commercial & 1340 & $1844^{\mathrm{a}}$ & 25 & 293 \\
Experimental & 472 & $1328^{\mathrm{b}}$ & 34 & 255 \\
Flying & 307 & $1993^{\mathrm{c}}$ & 37 & 326 \\
Small holders & 1407 & $1770^{\mathrm{d}}$ & 26 & 319 \\
\hline
\end{tabular}

* Means followed by different letters differ significantly $(\mathrm{p}<0.01)$

Small holdings are the dominant production system in Egypt as it contains about $95 \%$ of the total number of buffaloes in Egypt. The least squares means of total milk yield of buffaloes under this system was $1770 \mathrm{~kg}$ which is lower than the average milk yield of all buffalo herds $(1884 \mathrm{~kg})$. The buffaloes raised under this system usually receive special attention from the farmer and his family. Buffaloes under experimental herds had the lowest milk production $(1328 \mathrm{~kg})$. The differences 
between least squares means of total milk yield in different production systems was highly significant $(\mathrm{P}<0.01)$. Galal and Elbeltagy (2006) observed the same characteristics of different buffalo's production system in Egypt.

Table 4. Least squares means $(X)$ of total milk yield $(\mathrm{kg})$ and their standard error (SE) of buffaloes for different parities

\begin{tabular}{lccc}
\hline Parity & No. of records & $\mathrm{X}(\mathrm{kg})^{*}$ & SE \\
\hline 1 & 347 & $1579^{\mathrm{a}}$ & 34 \\
2 & 383 & $1718^{\mathrm{b}}$ & 33 \\
3 & 590 & $1722^{\mathrm{b}}$ & 29 \\
4 & 677 & $1780^{\mathrm{c}}$ & 28 \\
5 & 593 & $1795^{\mathrm{c}}$ & 28 \\
6 & 936 & $1808^{\mathrm{c}}$ & 27 \\
\hline
\end{tabular}

Table 4 shows the least squares means of total milk yield of buffalo in different parities. Under different production systems the number of parities of Egyptian buffaloes ranged from 1 to 6 parities. The total milk yield increases gradually from the first to the sixth parity. The least squares mean of total milk yield of second parity was higher than the first parity by $8 \%$ and different significantly $(\mathrm{P}<0.0001)$. No significant differences between total milk yield in second and third parities $(\mathrm{p}=0.92)$.Slight significant increase of about $62,77 \mathrm{and} 90 \mathrm{~kg}$ in total milk yield from the second to the fourth, fifth and sixth parities, respectively. The differences between total milk yield of fourth, fifth and sixth parities was not significant $(\mathrm{P}>0.05)$. Similar results observed by Badran et al. (2002).

\section{REFERENCES}

Abdel-Aziz, M and A. E. Badran, 2000. Effect of data imbalance and small herd size on the heritability estimated by different methods (a case study of milk yield in a buffalo herd). Alexandria Journal of Agricultural Research. 45(3):1.

Badran, A.E., A. El-Barbary, A. E. Mahdy and G.M. Assar, 2002. Genetic and nongenetic factors affecting the lifetime production traits in Egyptian buffaloes. Buffalo Journal. 18(2):235.

Bourdon, R.M., 1997. Understanding Animal Breeding. Prentic Hall, Upper Saddle River, New Jersey 07458, USA.

FAOSTAT. 2008. FAO Statistics Division., FAO, Rome, Italy, Accessed on www.fao.org.

Galal, S. and A. Elbeltagy, 2006. Achievement of research in the field of buffalo production in Egypt. WAAP Book of the Year 2006: 177.

Metry, G.H., J.C. Wilk, R.E. McDowell and H.A. El-Rigalaty, 1994. Factors affecting the performance of Egyptian buffalo. Annals of Agricultural Science, Moshtohor. 32:827.

Mourad, K.A. and M.M. Mohamed, 1995. Genetic and phenotypic aspects of milk yield traits and reproductive performance of Egyptian buffaloes. Egyptian Journal of Animal Production. 32: 125.

Mourad, K.A., M.M. Mohamed and A.S. Khattab, 1991. Genetic parameters for milk production traits in a closed herd of Egyptian buffaloes. Egyptian Journal of Animal Production. 28: 11.

SAS Procedures Guide, Version 8.2, 2001. SAS Inst., Inc., Cary, NC. 


\section{تحليل سجلات اللبن فى الجاموس تحت نظم إنتاج مختلفة}

سامح عبد الفتاح محمد عبد السلام، سامى أبو بكر، محمد عبد العزيز محمد إبراهيم، ريبع رجب صادق، أحمد سعيد عبد العزيز

قسم الإنتاج الحيوانس، كلية النزاعة، جامعة القاهرة، جيزة، مصر

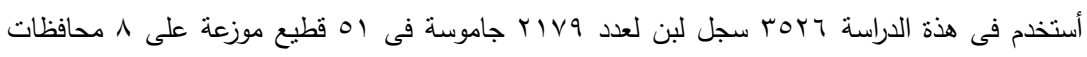

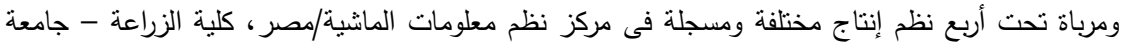

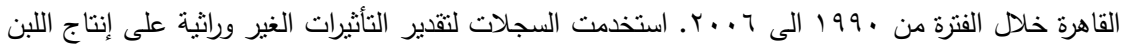

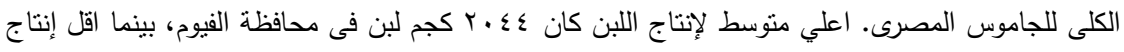

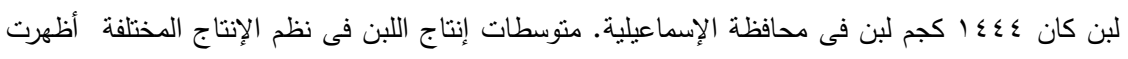

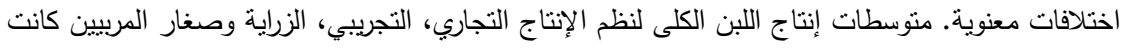

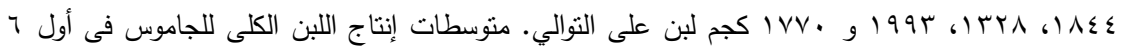

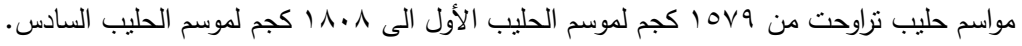

